\title{
EDUKASI LITERASI INFORMASI BAGI ANAK DAN REMAJA UNTUK MEMINIMALISIR PENYALAHGUNAAN MEDIA JEJARING SOSIAL
}

\author{
Siti Zulaiha, Sagiman, Mutia \\ Institut Agama Islam Negeri Curup, Indonesia \\ E-mail: sitizulaiha@iaincurup.ac.id
}

\begin{abstract}
The use of social networking media or commonly called social media in daily activities, has been carried out by all levels of society ranging from children, adolescents, to adults. Is that social media used as a medium for communication with various groups, as a medium of entertainment, as a medium for doing business, as a source of multiple information, and so forth. But in reality, social media is often misused, such as to post immoral content, hoaxes, hate speech, etc. that can harm users of social media and the wider community. Internet access that is not limited by space and time provides the opportunity in the use of social media anytime, anywhere, and by anyone. This will undoubtedly harm the use of social media. Therefore education is needed for social media users in utilizing social media, especially in receiving, analyzing, processing, and posting information well, especially for children and adolescents who tend to still lack knowledge about the negative impacts of social media abuse. These community service activities are carried out in the form of education and training on how to properly social media, the use of social media for positive things, and how the impact and legal sanctions in the event of social media abuse.
\end{abstract}

Keywords: Education, Literacy, Information

Abstrak. Penggunaan media jejaring sosial atau yang biasa disebut media sosial dalam aktifitas keseharian sudah dilakukan oleh semua kalangan masyarakat mulai dari anak-anak, remaja, sampai ke orang dewasa. Apakah itu media sosial digunakan sebagai media untuk komunikasi dengan berbagai kalangan, sebagai media hiburan, sebagai media untuk berbisnis, sebagai sumber berbagai informasi, dan lain sebagainya. Namun pada kenyataannya media sosial sering kali disalahgunakan, seperti untuk memposting konten-konten yang asusila, hoax, ujaran kebencian, dan lain sebagainya yang dapat memberikan dampak negatif bagi pengguna media sosial dan masyarakat luas. Akses internet yang tidak terbatas oleh ruang dan waktu memberikan kesempatan dalam penggunaan media sosial kapan saja, dimana saja, dan oleh siapa saja. Hal ini tentunya akan berdampak pada penggunaan media sosial yang negative. Oleh sebab itu diperlukan edukasi terhadap pengguna media sosial dalam memanfaatkan media sosial terutama dalam menerima, menelaah, mengolah, dan memposting informasi dengan baik, terutama bagi kalangan anak-anak dan remaja yang cenderung masih minim pengetahuan tentang dampak negatif dari penyalahgunaan media sosial. Kegiatan pengabdian ini dilakukan dalam bentuk edukasi dan pelatihan tentang bagaimana bermedia sosial yang benar, penggunaan media sosial untuk hal-hal yang positif, dan bagaimana dampak dan sanksi hukum apabila terjadi penyalahgunaan media sosial.

Kata Kunci: Edukasi, Literasi, Informasi

Permalink/DOI: https://doi.org/10.15408/harkat.v15i2.13469 


\section{Pendahuluan}

Istilah "media sosial" saat ini sudah tidak asing lagi di mata dunia. Semua kalangan telah mendengar dan mengenal baik istilah tersebut mulai dari anak-anak hingga dewasa. Bahkan hampir setiap detik, media sosial selalu dibuka, entah hanya untuk melihat- lihat, membaca, atau mengkritik sesuatu yang muncul dari media sosial. Media sosial adalah media yang berupa situs dan aplikasi yang melibatkan teknologi berbasis internet. Media berbasis teknologi internet ini mendorong dan memungkinkan penggunaannya saling terhubung dengan siapa saja, baik orang-orang terdekat hingga orang asing yang tidak pernah dikenal sebelumnya. Informasi yang biasanya dibagikan pada media sosial tidak hanya informasi yang bersifat umum seperti berita dan hiburan, tetapi juga informasi yang bersifat pribadi seperti foto, video, dan identitas diri. Pada tahap tersebut, media sosial dapat membuat informasi pribadi yang dibagikan memasuki ranah publik yang dapat diakses oleh orang lain. Media sosial sebagai media yang dapat digunakan untuk menyalurkan hobi, sebagai sarana hiburan seperti bermain game online atau hanya sekedar melihat-lihat foto dan video. Selain itu, media sosial sebagai tempat kegiatan komersil berlangsung seperti melakukan promosi untuk menjual produk tertentu (Miller et.al, 2016) dalam (Triastuti, Adrianto, \& Nurul, 2017). Sehingga, kemudian keberadaan media sosial tersebut bagaikan dua sisi mata uang yang berbeda yaitu memberikan dampak positif dan negatif bagi kehidupan. Di satu sisi, media sosial dapat membantu menguasai teknologi sesuai dengan tuntutan zaman pada era digital ini dan satu sisi lain, media sosial dapat merusak komunikasi anak dengan orang tua, komunikasi dengan teman di dunia nyata, dan menjadi lahan kejahatan bagi orang yang tidak bertanggung jawab serta dampak negatif lainnya yang dirasakan saat ini. Kurnia, Wendratama, Adiputra, \& Poerwaningtias, 2017) juga mengemukakan bahwa internet sering dianggap memberikan dampak negatif karena alasan konten, seperti pornografi, kekerasan, dan cyberbullying.

Studi yang dilakukan Christina Davidson (2011) dalam (Kurnia et al., 2017) menunjukkan bahwa internet bisa digunakan secara positif oleh anak-anak di rumah. Melalui kasus yang sederhana, Davidson (2011) dalam (Kurnia et al., 2017) juga menunjukkan bahwa untuk bisa menggunakan internet dengan positif, anak-anak membutuhkan bimbingan orangtua dan untuk dapat melakukan pembimbingan orangtua dituntut mempunyai kecakapan baik teknis, pengetahuan, maupun emosi dalam mengakses berbagai informasi maupun hiburan melalui internet. Namun, dampak negatif lebih dirasakan daripada dampak positif, khususnya anak dan remaja yang sudah semakin candu dengan penggunaan media sosial. Dilihat dari kondisi masyarakat secara umum, orang tua saat ini sudah bebas memberikan Android kepada anaknya tanpa mengenal usia dan waktu serta tanpa bimbingan, karena anakanak yang sudah semakin sulit diatur dan kesibukan orang tuanya. Padahal anak dan remaja masih membutuhkan kasih sayang dan perhatian lebih dari orang tuanya.

Berdasarkan data dari survey yang dilakukan oleh We Are Sosical Singapore pada tahun 2017, jumlah penduduk Indonesia yang menggunakan media sosial adalah 106 juta jiwa dari total 262 juta jiwa populasi, yang 92 juta jiwa di antaranya mengakses media sosial dari perangkat mobile. Sementara, data dari survey yang sama menunjukkan bahwa dalam aktivitas tertinggi yang dilakukan oleh pengguna internet Indonesia dalam kurun waktu satu minggu adalah mengunjungi media sosial dengan rincian $62 \%$ menggunakan telepon pintar, 16\% menggunakan komputer (desktop) dan 6\% menggunakan tab (Triastuti et al., 2017).

Media sosial mengajak siapa saja yang tertarik untuk berpartisipasi dengan memberi feedback secara terbuka, memberi komentar, 
serta membagi informasi dalam waktu yang cepat dan tak terbatas. Remaja-remaja yang mempunyai media sosial seringkali memposting foto-foto baik selfie maupun welfie bersama teman, kegiatan pribadi, serta curhatan antar teman di media sosial. Dalam media sosial siapapun dapat dengan bebas berkomentar serta menyalurkan pendapatnya tanpa rasa khawatir. Hal ini dikarenakan dalam internet khususnya media sosial sangat mudah memalsukan jati diri atau melakukan kejahatan. Padahal dalam perkembangannya di sekolah, remaja berusaha mencari identitasnya dengan bergaul bersama teman sebayanya. Namun, saat ini seringkali remaja beranggapan bahwa semakin aktif dirinya di media sosial maka mereka akan semakin dianggap keren dan gaul. Sedangkan remaja yang tidak mempunyai media sosial biasanya dianggap kuno atau ketinggalan jaman dan kurang bergaul (Wilga Secsio Ratsja Putri, Nurwati, \& Budiarti S., n.d.).

Kata remaja (adolescence) berasal dari kata adolescere (latin) yang berarti tumbuh ke arah kematangan (Muss, 1968 dalam (Sarwono, 2011)). Remaja merupakan masa peralihan dari anak-anak menuju kedewasaan. Hurlock (1990) dalam (Herlina, 2013) membagi masa remaja menjadi dua yaitu masa remaja awal (11/12 16/17 tahun) dan remaja akhir (16/17 - 18 tahun). Namun, Monks, Knoers, dan Haditono dalam (Wilga Secsio Ratsja Putri et al., n.d.) membedakan masa remaja menjadi empat bagian, yaitu masa pra-remaja $10-12$ tahun, masa remaja awal $12-15$ tahun, masa remaja pertengahan 15 - 18 tahun, dan masa remaja akhir 18 - 21 tahun. Pada masa remaja akhir, individu sudah mencapai transisi perkembangan yang lebih mendekati masa dewasa. Masa remaja merupakan masa pencarian jati diri, mencari perhatian, mencari teman sebanyak-banyaknya, dan mencari perlindungan sesuai dengan yang dikemukakan oleh Krori sebagai berikut bahwa masa remaja merupakan suatu periode penting dari rentang kehidupan, suatu periode transisional, masa perubahan, masa usia bermasalah, masa dimana individu mencari identitias diri, usia menyeramkan (dreaded), masa unrealism, dan ambang menuju kedewasaan (Krori, 2011). Sebagai akibatnya, kemudian kalangan remaja tersebut menjadi hiperaktif di media sosial dan sering memposting kegiatan sehari-hari yang seakan-akan menggambarkan kehidupan mereka secara nyata atau sesuatu yang tidak sesuai dengan kehidupan sosialnya hanya ingin menutupi kesepiannya atau kehidupannya yang sebenarnya.

Data survey yang dilakukan oleh Asosiasi Penyelenggara Jasa Internet Indonesia (APJII, 2016) menunjukkan bahwa 132,7 juta dari 256 , 2 juta ( 51,8\%) masyarakat Indonesia menggunakan internet pada tahun 2016. Yang menarik dari survei 2016 ini adalah persebaran pengguna internet berdasarkan umur tidak cukup merata. Data menunjukkan pada kelompok usia 10-24 tahun pengguna internet sebesar $18,4 \%$, usia $25-34$ tahun sebesar $24,4 \%$, usia

35-44 tahun sebesar 29,2\%, usia 45-54 tahun sebesar $18 \%$, dan usia 55 tahun ke atas sebesar 10\%. Dibandingkan dengan data dua tahun sebelumnya persebaran pengguna internet ini menunjukkan adanya perbedaan. Survei oleh APJII pada tahun 2014 menunjukkan, penggunaan internet pada kelompok umur 1825 tahun sebesar 49\%, umur 26-35 tahun $33.8 \%$, umur $36-45$ tahun $14,6 \%$, umur $46-55$ tahun 2,4\%, dan umur 56-65 tahun 0,2\%. Berdasarkan data APJII tahun 2016 dan 2014 di atas tampak jelas perbedaannya. Jika pada tahun 2014 usia termuda dalam menggunakan internet adalah 18 tahun maka pada tahun 2016 usia termuda adalah 10 tahun. Ini menunjukkan bahwa ada kecenderungan usia pengguna internet semakin lama semakin muda. Di samping data tersebut, dalam kehidupan seharihari, pengguna internet di bawah usia 10 tahun juga banyak dijumpai. Di berbagai ruang publik seperti pusat perbelanjaan, restoran, dan 
bandara, sering ditemukan anak usia 3-9 tahun sibuk dengan perangkat gadget, baik berupa telepon genggam atau tablet. Gadget tersebut mereka gunakan untuk mengakses game atau film melalui internet. Saat berhubungan dengan internet, anak- anak juga menunjukkan kecenderungan lebih mudah beradaptasi dengan teknologi digital dibandingkan dengan orang dewasa (Harrison \& McTavish, 2016) dalam (Kurnia et al., 2017).

Selanjutnya, Candra (2013) dalam (Kurnia et al., 2017) juga menjelaskan bahwa studi kuantitatif yang dilakukan oleh Puspita Adiyani Candra (2013:7-8) terhadap 100 anak sekolah menyimpulkan bahwa internet telah dikenal sejak usia lima tahun (balita) atau bahkan sebelumnya. Data menunjukkan $12 \%$ anak-anak telah mengenal internet pada usia 5 tahun, $4 \%$ pada usia 4 tahun, dan $1 \%$ pada usia 3 tahun Dari temuan penelitian tersebut terlihat pengguna internet berusia muda dan bahkan perkenalan mereka dengan internet dimulai di usia balita.

Sosial media saat ini telah menjadi tempat bagi jutaan umat manusia untuk berkumpul. Berbagai produk yang ditawarkan seperti blogspot, wordpress, facebook, twitter, instagram, youtube dan berbagai layanan berbasis jejaring sosial (social network) telah menjadi lahan subur bagi penggunanya untuk berinteraksi dengan banyak orang di berbagai belahan dunia. Melalui layanan-lanyanan sosial media itu pula para pengguna dapat berbagi informasi bermanfaat seputar aktivitas yang sedang dikerjakan, ide, gagasan, opini dan tulisan ilmiahnya. Dari sekian banyak jejaring sosial media yang ada di dunia maya, facebook dan twitter merupakan layanan sosial media yang paling banyak digunakan oleh netizen (pengguna sosial media) (Nugraha, 2017).

Hal ini sebagaimana data yang dikemukakan oleh Triastuti bahwa Pengguna media sosial Facebook Indonesia menduduki peringkat 2 dunia setelah Bangkok, yaitu sebanyak 11.658.700 jiwa. Sementara, pengguna Twitter di Indonesia menduduki peringkat ke lima dunia setelah Amerika, Brazil, Jepang dan Inggris. Perilaku bermedia social di Indonesia juga menunjukkan konsistensi yang sama pada semua kelompok umur. Adapun pilihan media sosial terbanyak di Indonesia, yaitu Facebook, Instagram dan Twitter. Alasan utama orang Indonesia bermedia sosial adalah untuk bersosialisasi. Tiga aktivitas utama yang dilakukan oleh orang Indonesia ketika menggunakan media sosial adalah memperbaharui status, memposting foto dan membagikan artikel gaya hidup. Anak-anak dan remaja mencoba berbagai media sosial dan pesan instan. Media sosial yang mereka coba misalnya: Facebook, Whatsapp, Instagram, Snapchat, LINE, Google+, Youtube, BBM, Joox, Wattpad, Musical.ly, Vine, dan yang lain. Media sosial yang mereka coba misalnya: Facebook, Whatsapp, Instagram, Snapchat, LINE, Google+, Youtube, BBM, Joox, Wattpad, Musical.ly, Vine, dan yang lain (Triastuti et al., 2017).

Selain itu, latar belakang yang menjadikan layanan facebook dan twitter sebagai sosial media terfavorit bukanlah tanpa alasan. Banyaknya fitur yang ditawarkan dengan berbagai kelebihan dari aplikasi ini yang kemudian menjadi faktor utama netizen lebih memilih menggunakan facebook dibandingkan dengan layanan sosial media lainnya. Lebih lanjut dilihat dari subtansi, jika, facebook lebih menonjolkan bagi diri atau personal seseorang sehingga hal ini menjadi lebih mudah 'terendus' segi narsisismenya, maka twitter justru menampung eksistensi seseorang dengan cara yang lebih sedikit elegan. Sebagai contoh apabila kita mengetik kata kunci misalnya Michael Jackson, bisa saja kata ini sedang banyak dicari dan menjadi trending topics yang membuat pengguna akun twitter lainnya penasaran dan ingin tahu 'ada apa dengan Michael Jackson'. Dari hal tersebut itu pula tidak berlebihan jika 
portal berita televisi internasional dan lokal seperti CNN, BBC, Kompas, Trans TV dan lainnya juga memiliki akun facebook dan twitter. Penggunaan jejaring sosial media ini juga menjadi sebuah fenomena yang terbilang cukup dahsyat atau bombastis (Nugraha, 2017).

Berkenaan dengan kondisi di atas, maka perlu bagi anak dan remaja untuk mendapatkan literasi terkait dengan penggunaan media sosial dengan cara membangun pendidikan literasi anak dan remaja secara utuh baik oleh orang tua, guru, maupun yang dilakukan secara pendampingan bersama-sama antara pihak-pihak yang terlibat dalam membangun edukasi literasi tersebut.

Pentingnya pemberian edukasi literasi informasi ini juga sesuai dengan pernyataan berikut bahwa media literasi juga menjadi semacam jawaban atau solusi atas berbagai masalah seputar dampak media terhadap penggunanya. Hal ini karena menurut Azimah Soebagijo (2008) dalam (Nugraha, 2017), tujuan media literasi adalah memberikan pemahaman kepada seseorang tentang manfaat dan kerugian dari media massa.

Setiap orang hendaknya perlu untuk mengembangkan keahlian melek media. Terutama dalam menyikapi pesan-pesan dari media yang semakin canggih dalam hal mempengaruhi cara berpikir, merasa, bersikap dan berperilaku. Jika di Amerika Utara sejak tahun 1978 media literasi telah menjadi salah satu topik penting kurikulum pendidikan di sekolah-sekolah, maka di Indonesia media literasi seharusnya sudah diintegrasikan ke dalam kurikulum pelajaran di kelas sebagai salah satu keterampilan dasar berkomunikasi. Menjadi melek media memerlukan keterampilan berpikir kritis yang menuntun sesorang agar dapat mengambil berbagai informasi terkait dengan informasi di media masa dan berguna bagi kehidupannya. Sehingga orang yang menguasai ilmu tentang melek media akan memahami proses komunikasi yang disajikan media. Mereka akan mampu mengubah dan merespon pesan dalam media menjadi lebih komprehensif, utuh dan sesuai dengan tuntutan norma yang berlaku di masyarakatnya (Nugraha, 2017).

Berdasarkan isu dan fokus masalah yang dikemukakan di atas, maka penting dilakukan edukasi literasi informasi sebagai upaya meminimalisir penggunaan media sosial dengan judul "Edukasi Literasi Informasi Bagi Anak Dan Remaja Untuk Meminimalisir Penyalahgunaan Media Jejaring Sosial”.

Permasalahan media sosial tidak hanya dialami pada anak dan remaja di wilayah perkotaan saja, akan tetapi juga telah dialami oleh anak dan remaja di wilayah pedesaan seperti di daerah Kecamatan Selupu Rejang Kabupaten Rejang Lebong Provinsi Bengkulu. Selupu Rejang merupakan salah satu kecamatan di Kabupaten Rejang Lebong yang telah maju dengan masyarakatnya yang cukup makmur dengan mata pencaharian utamanya adalah berkebun dan berdagang. Kecamatan Selupu Rejang saat ini telah memiliki 14 Desa antara lain Air Duku, Air Meles Atas, Air Putih Kali Bandung, Cawang Baru, Cawang Lama, Kali Padang, Kampung Baru, Karang Jaya, Kayu Manis, Sambirejo, Simpang Nangka, Suban Ayam, Sumber Bening, dan Sumber Urip ("Daftar Desa \& Kelurahan di Kecamatan Curup Kab. Rejang Lebong,” n.d.).

Selupu Rejang juga memiliki topografi yang berbukit sehingga tidak heran jika tidak semua desa di daerah kecamatan ini memilki signal yang baik, namun kehidupan masyarakatnya sudah lebih baik dan maju. Mayoritas penduduknya adalah suku Rejang dan Lembak. Namun, saat ini telah banyak Suku Jawa dan Padang yang menjadi penduduk tetap di kecamatan tersebut. Banyak anak-anak dan remajanya yang menuntut ilmu ke Pulau Jawa dan kemudian kembali lagi mengabdi di desanya. Bangunan dan fasilitas daerahnya juga sudah cukup baik dan kegiatan-kegiatan kemasyarakatannya juga beragam. Selain itu, 
secara umum, anak-anak dan remajanya juga telah banyak menggunakan android dalam kehidupannya sehari-hari bahkan sudah banyak mengenal website dan bentuk media sosial lain sebagainya meskipun masih terdapat beberapa desa dan kelurahan yang tidak memiliki signal yang baik.

Adapun yang akan menjadi subjek dampingan dalam pengabdian ini adalah anakanak dan remaja yang telah dikategorikan sebagai anak dan remaja berdasarkan teori perkembangan anak yaitu anak- anak yang berusia $3-11$ tahun dan remaja yang dimulai dari usia 11 hingga 21 tahun sebagai pengguna media sosial yang cukup banyak presentasenya dan dimediasi oleh orang-orang sekitarnya. Sementara, seharusnya pada usia anak dan remaja itu bukan usia untuk diperkenalkan media sosial melainkan lebih banyak dikenalkan pada kehidupan bermain anak dan remaja sesuai dengan usianya. Akan tetapi, kenyataannya saat ini, kehidupan bermedia sosial anak dan remaja tidak bisa dielakkan lagi sebab orang tua sebagai mediator utama telah memperkenalkan hal tersebut kepada anak-anaknya. Begitu juga dengan kondisi anak- anak dan remaja di kecamatan Selupu Rejang sebagai kondisi dampingan dalam pengabdian ini. Orang tua mereka banyak yang bekerja ke kebun dan berdagang sehingga anak-anaknya sering ditinggalkan dan kemudian dibelikan android serta diberikan kebebasan secara leluasa dalam penggunaannya. Hal ini sesuai dengan apa yang dikemukakan oleh Candra (2013) dalam (Kurnia et al., 2017) menjelaskan bahwa interaksi anak-anak dalam usia 3 hingga 12 tahun dengan internet secara umum dimediasi oleh orang-orang di sekitarnya. Orang-orang yang memiliki peran memperkenalkan internet untuk pertama kalinya pada anak-anak, antara lain: orangtuanya (45\%), anggota keluarga lain selain orangtua seperti kakak, sepupu atau paman, dan bibi (29\%), guru (11\%), dan teman (2\%). Anak-anak yang menyatakan belajar sendiri secara autodidak sebanyak 10\%. Adapun lokasi penggunaan internet secara umum merujuk pada tiga lokasi utama: rumah (51\%), ruang publik seperti

pusat perbelanjaan atau restoran yang menyediakan Wi-Fi (30,4\%), dan sekolah (18.5\%).

Adapun yang dimaksud pada proposal ini atau yang menjadi sasaran di sini pada lokasi pertama yakni rumah dan sekolah. Hal ini sesuai dengan kondisi kecamatan Selupu Rejang yang masih jarang ditemui pusat perbelanjaan dan restoran yang menyediakan jaringan Wi-Fi, sehingga siswa banyak mengakses internet di lingkungan rumah dan sekolah.

Berdasarkan survey wilayah dan kondisi dampingan di atas yang didapatkan pengabdi saat berkunjung ke lokasi tersebut, maka pengabdi tertarik memilih anak dan remaja dalam kecamatan ini sebagai subjek dampingan dalam pengabdian berbasis riset unggulan nasional tahun 2019.

\section{METODE}

Metode yang digunakan dalam pengabdian ini yaitu Participatory Action Research (PAR), dimana proses yang diawali dengan riset awal terkait dengan permasalahan yang dialami oleh subyek dan kemudian diberikan aksi untuk memberikan solusi dan pemberdayaan dari permasalahan tersebut, namun dalam PAR juga dilakukan evaluasi terhadap aksi yang telah dilakukan melalui refleksi bersama degan subyek dampingan kemudian bisa menjadi bahan perbaikan pada aksi berikutnya sehingga hasil yang diharapkan bisa optimal dan sesuai dengan yang diharapkan.

Adapun langkah-langkahnya dapat dijabarkan sebagai berikut :

1. Riset pendahuluan

Pengabdi melakukan riset awal ke sekolah yang ada di wilayah Kecamatan Selupu Rejang guna mengamati perilaku anak di sekolah terutama dalam penggunaan media sosial baik 
ketika dalam penggunaan fasilitas sekolah maupun HP pribadi dan mengamati perilaku anak, kebiasaan mereka di lingkungan rumah dan masyarakat sekitar.

2. Membangun kepercayaan masyarakat melalui inkulturasi

Pengabdi membaur dengan masyarakat guna membangun rasa percaya masyarakat baik sekolah maupun orangtua siswa yang menjadi sasaran atau subyek dampingan dalam pengabdian ini.

3. Mengorganisasi subyek sasaran, menganalisis masalah dan merumuskan masalah

4. Membuat kelompok sasaran yang akan didampingi baik di sekolah maupun orangtua siswa, kemudian dilakukan FGD sebagai wadah untuk menganalisis permasalahan-permasalahan yang dihadapi oleh anak maupun orangtua terkait dengan penggunaan media sosial anak baik di sekolah maupun di rumah, apa penyebabnya dan bagaimana dampak positif maupun negatifnya. Kemudian dirumuskan masalah yang harus dipecahkan dan memilah mana masalah yang harus segera ditangani atau diberikan tindakan terlebih dahulu dan tindakan lanjutan.

5. Merencanakan tindakan aksi

Pengabdi menyusun rencana aksi sesuai dengan hasil rumusan masalah pada langkah sebelumnya dan dikoordinasikan bersama pihak sekolah maupun orangtua siswa. Setelah itu pengabdi mengkroscek potensi sekolah dan masyarakat yang meliputi tempat pelaksanaan kegiatan dan SDM yang menjadi sasaran pendampingan serta menentukan pihak-pihak yang terlibat di dalamnya. Selesai itu pengabdi membuat strategi aksi yang akan dilaksanakan dalam kegiatan pendampingan.

\section{Aksi}

Hasil dari rencana aksi yang telah disusun kemudian diimplementasikan yang disesuaikan dengan jadwal kegiatan yang telah disusun serta sesuai dengan urutan kegiatan yang sesuai rencana aksi tersebut.

7. Evaluasi

Evaluasi dilakukan dengan cara mengkroscek apakah kegiatan yang dilakukan sesuai dengan strategi implementasi dan sharing knowledge yang telah disusun serta kesesuaian dengan output yang diharapkan atau tidak. Sehingga pengabdi bisa membuat perbaikan strategi implementasi pada kegiatan-kegiatan selanjutnya.

8. Refleksi

Pengabdi dan siswa serta orangtua merefleksikan kegiatan-kegiatan yang telah dilakukan (baik proses maupun hasil). Kemudian hasil refleksi bisa dijadikan sebagai pertimbangan untuk perbaikan teoritis maupun praktis terkait dengan edukasi literasi informasi di sekolah bagi anak dan remaja (digilib.uinsby.ac.id/.pdf).

\section{HASIL}

Adapun kata literasi diambil dari istilah literacy, Inggrisyang diartikan sebagai kemampuan membaca dan menulis. Pada masyarakat modern membaca dan menulis sudah menjadi salah satu bentuk kecakapan hidup (life style) sekaligus bagian paling mendasar dari sekian banyak kegiatan yang dilakukan manusia di dalam kehidupannya. Bagi manusia modern, tanpa membaca dan menulis mereka akan ketinggalan informasi penting dalam kehidupannya. Mereka akan termarginalkan serta hilang ditelan perubahan zaman. Budaya literasi sebenarnya mulai mengalami peningkatan dalam hal eksistensinya ketika individu berada pada lingkungan pendidikan/ sekolah. Meskipun demikian, faktanya budaya literasi dalam suatu negara tidak hanya dipengaruhi oleh motivasi seseorang melainkan juga turut dipengaruhi oleh unsur-unsur tradisi dan budaya yang ada dalam masyarakat sekitarnya. Tidak mengherankan jika semakin tinggi minat baca dalam suatu masyarakat, maka semakin tinggi pula indikator 
budaya literasi yang dimilikinya (Nugraha, 2017).

Adapun hasil dari kegiatan pengabdian ini dituangkan dalam tahapan-tahapan sebagai berikut :

\section{Perencanaan}

Kegiatan literasi edukasi informasi ini dilakukan dalam bentuk pelatihan dan sosialisasi. Adapun yang menjadi sasaran kegiatan ini adalah anak-anak dan remaja usia sekolah dasar, sekolah tingkat pertama dan menengah. Dan kegiatan ini diawali dengan survei ke lokasi lebih tepatnya ke desa dan kelurahan di lingkup kecamatan Curup Tengah dan menyebarkan undangan peserta kegiatan sekaligus menentukan tempat kegiatan sosialisasi dalam hal ini akan dilakasanakan pada 3 lokasi atau tempat yaitu di desa Air Merah, Kelurahan Talang Rimbo dan Kelurahan Air Bang.

\section{Pelaksanaan}

Pada tahap pelaksanaan kegiatan berupa pelatihan dan sosialisasi literasi edukasi penggunaan jejaring media sosial ini, kami tim pengabdi bertindak sebagai pemateri dalam memberikan pemahaman anak dan remaja dalam penggunaan jejaring media sosial. Di mana selama ini belum ada kegiatan yang memberikan pemahaman terhadap anak dan remaja tentang hal tersebut. Selain itu kegiatan ini diharapkan dapat menjadi langkah awal dalam pencegahan penyalahgunaan jejaring media sosial.

Materi yang disampaikan berupa informasi terkait dengan literasi informasi dan bagaimana penggunaan media jejaring sosial yang positif, serta dampak yang ditimbulkan oleh penggunaan media jejaring sosial. Adapun halhal yang disampaikan antara lain : 1). Informasi tentang manfaat dari internet, 2). Resiko ketika internet tidak digunakan dengan bijak, 3). Jenisjenis media sosial, 4). Fungsi media sosial, 5). Informasi berkaitan dengan Perundang- undangan yang mengatur tentang Informasi dan Transaksi Elektronik (UU ITE).

Adapun dokumentasi kegiatan dapat dilihat seperti gambar-gambar berikut :

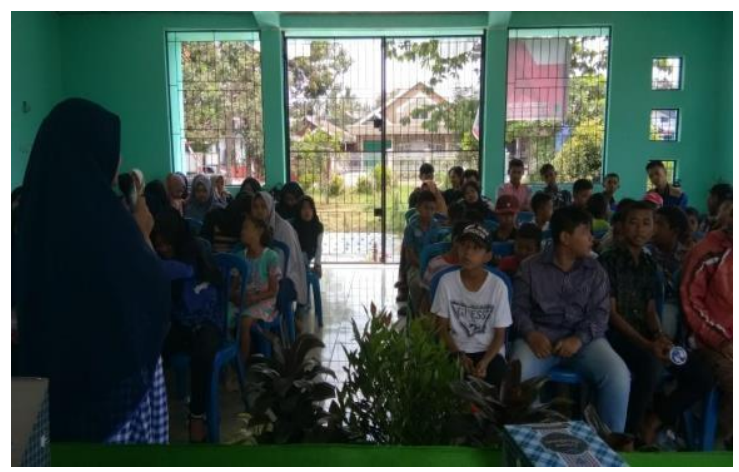

Gambar 1: Pelaksanaan Edukasi di Kelurahan Air Bang

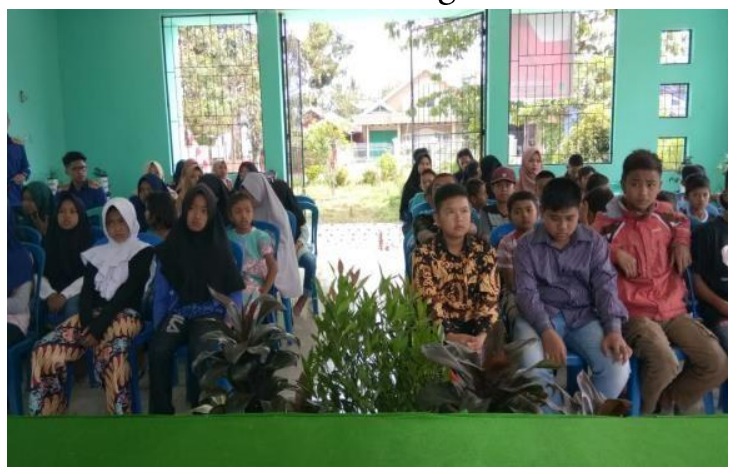

Gambar 2: Peserta Edukasi di Kelurahan Air Bang

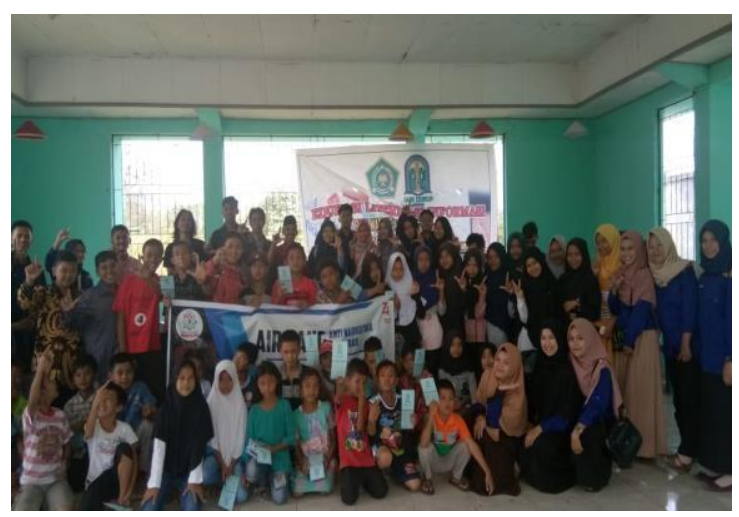

Gambar 3 : Foto bersama setelah kegiatan di Kelurahan Air Bang 


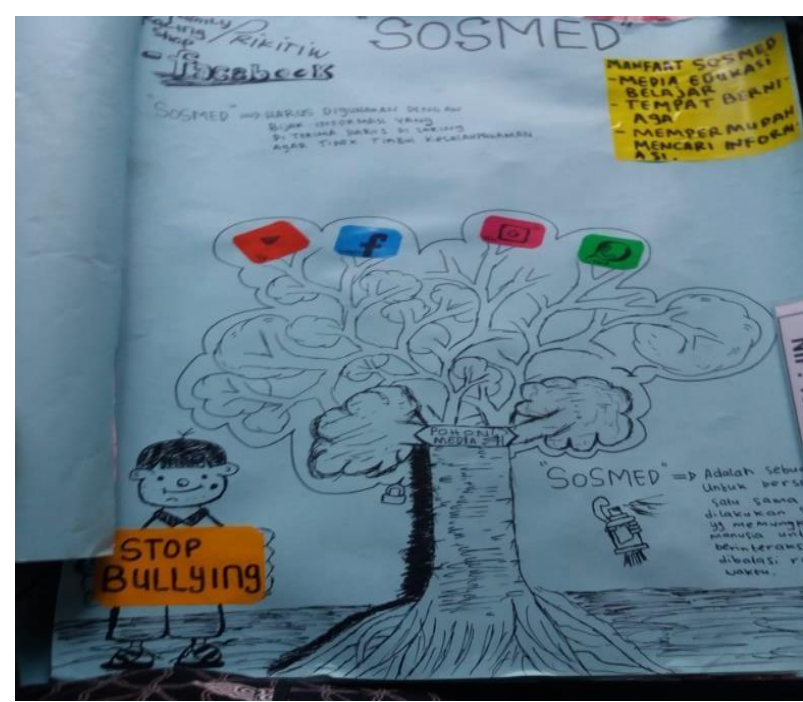

Gambar 4 : Hasil karya peserta

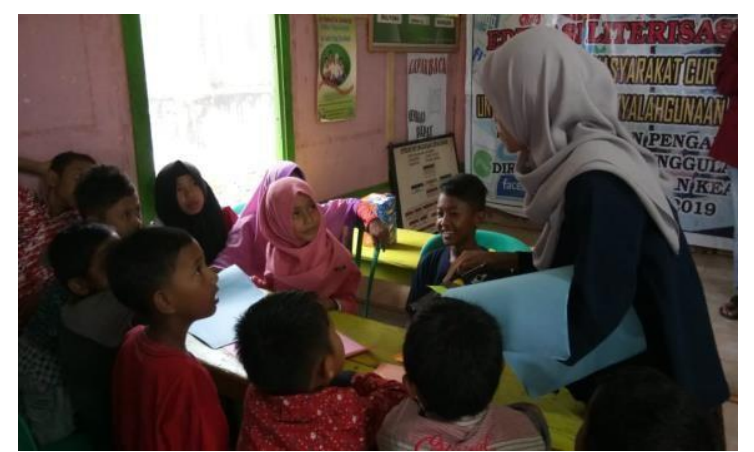

Gambar 5 : Kerja Kelompok peserta

\section{Evaluasi}

Kegiatan selanjutnya untuk melihat apakah kegiatan sosialiasasi berhasil atau tidak dilakukanlah proses evaluasi berupa pre test dan post test dengan teknik tes tertulis bentuk pilihan ganda. Kegiatan ini dilakukan untuk mengukur sejauh mana pengetahuan peserta tentang literasi informasi, tentang penggunaan alat ICT, manfaat internet, dan tentang media sosial sebelum dan sesudah pelaksanaan sosialisasi dan pelatihan. Adapun gambaran tingkat kompetensi yang harus dicapai oleh peserta dan instrumennya dijelaskan dalam tabel berikut ini :
Tabel 1 : Instrumen Pre Test dan Post Test

\begin{tabular}{|c|c|c|c|c|}
\hline$\overline{\text { No }}$ & $\begin{array}{l}\text { Tingkat } \\
\text { Kompetensi }\end{array}$ & Butir Soal & $\begin{array}{l}\text { Jml } \\
\text { Soal }\end{array}$ & Prosentase \\
\hline$\overline{1}$ & $\begin{array}{l}\text { Mengetahui } \\
\text { pemahaman } \\
\text { peserta tentang } \\
\text { literasi dan } \\
\text { informasi }\end{array}$ & 1,2 & 2 & 20 \\
\hline 2 & $\begin{array}{l}\text { Meningkatkan } \\
\text { pengetahuan } \\
\text { peserta tentang } \\
\text { gadget } \\
\text { dan fungsinya }\end{array}$ & 3,4 & 2 & 20 \\
\hline$\overline{3}$ & $\begin{array}{l}\text { Meningkatkan } \\
\text { pengatahuan } \\
\text { peserta tentang } \\
\text { manfaat } \\
\text { internet dan } \\
\text { dampaknya }\end{array}$ & 5,6 & 2 & 20 \\
\hline 4 & $\begin{array}{l}\text { Meningkatnya } \\
\text { pengetahuan } \\
\text { peserta tentang } \\
\text { media }\end{array}$ & $\begin{array}{l}7,8,9 \\
\text { dan } 10\end{array}$ & 4 & 40 \\
\hline
\end{tabular}

Pada pelaksanaan kegiatan literasi edukasi informasi bagi anak dan remaja di Curup Tengah dalam meminimalisir penyalahgunaan jejaring media sosial hasil yang telah dicapai antara lain :

1) Mampu memahami tentang bagaimana penggunaan jejaring gadget dan internet dengan baik dan sehat.

2) Mampu menggunakan jejaring media sosial dengan cerdas.

3) Mampu memilah dan memilih informasi dalam jejaring media sosial yang mereka gunakan

4) Mampu memahami aturan perundangundangan yang mengatur tentang Informasi dan Transaksi Elektronik.

\section{Penutup}

Setelah dilaksanakannya kegiatan ini maka dapat ditarik kesimpulan sebagai berikut :

1. Kegiatan edukasi literasi informasi bagi anak- anak dan remaja dalam rangka meminimalisir penyalahgunaan media 
jejaring sosial sangatlah penting untuk dilaksanakan.

2. Media jejaring sosial sangatlah mudah untuk disalahgunakan untuk hal-hal yang negative seperti penyebaran konten asusila, hoax, dan ujaran kebencian.

3. Kegiatan edukasi literasi informasi bagi anak- anak dan remaja dapat meminimalisir bahkan mencegah terjadinya penyalahgunaan media jejaring sosial.

4. Pemahaman tentang bagaimana menerima, mengolah, dan menyebarkan informasi sangatlah penting untuk diberikan, sehingga penyalahgunaan media jejaring sosial dapat diminimalisir.

\section{Daftar Pustaka}

Daftar Desa \& Kelurahan di Kecamatan Curup Kab. Rejang Lebong.(n.d.). Retrieved from (http://www.nomor.net/ kodepos.php? i=des a- $\quad$ kodepos\&daerah=Kecamatan-Kab.Rejang+Lebong\&jobs=Rejang+Lebong\&urut= \&asc $=0$ 00010\&sby $=000000 \&$ no $1=2 \&$ prov $=$ Selupu + Rejang).

Fardiah, D., Rinawati, R., \& Indra Karsa, S. (2015). LITERASI INTERNET DALAM MEMINIMALISASI DAMPAK NEGATIF MEDIA JEJARING SOSIAL. Prosiding SNaPP Sosial, Ekonomi, Dan Humaniora.

Herlina. (2013). Bibliotherapy:Mengatasi Masalah anak dan Remaja melalui Buku. Bandung: Pustaka Cendekia Utama.

Krori, S. D. (2011). Development

Psychology. Homeopathic

Journal, 4(3). Retrieved from

http://www.homeorizon.com/homeopathicarticles/psychology/development-psychology

Kurnia, N., Wendratama, E., Adiputra, W. M., \& Poerwaningtias, I. (2017). LITERASI DIGITAL KELUARGA: Teori dan Praktik Pendampingan Orang Tua Terhadap Anak dalam Berinternet. Yogyakarta: CENTER FOR DIGITAL SOCIETY (CFDS) FAKULTAS ILMU

\section{SOSIAL DAN ILMU POLITIK UNIVERSITAS GADJAH MADA}

Nugraha, M. T. (2017). BUDAYA LITERASI DAN PEMANFAATAN SOSIAL MEDIA PADA MASYARAKAT AKADEMIK. At-Turats : Jurnal Pemikiran Pendidikan Islam, 11(2), 124-132.

Metode Partisipatory Action Research : digilib.uinsby.ac.id/20834/6/Bab\%203.pdf

Sarwono, S. (2011). Psikologi Remaja. Jakarta: PT Rajagrafindo Persada.

Triastuti, E., Adrianto, D., \& Nurul, A. (2017). Kajian Dampak Penggunaan Media Sosial Bagi Anak dan Remaja: Seri Literasi Digital. Pusat Kajian Komunikasi, FISIP Universitas Indonesia.

Wilga Secsio Ratsja Putri, R., Nurwati, N., \& Budiarti S.,

M. (n.d.). PENGARUH MEDIA SOSIAL TERHADAP PERILAKU REMAJA. PROSIDING KS: RISET \& PKM, 3(1). Retrieved from http://jurnal.unpad.ac.id/prosiding/article/vie wFile/136 25/6455 